\title{
Technical challenges in evaluating southern China's forage germplasm resources
}

\author{
BAI CHANGJUN, LIU GUODAO, ZHANG YU, YU DAOGENG AND YAN LINLING
}

Tropical Crops Genetic Resources Institute, Chinese Academy of Tropical Agricultural Sciences (CATAS), Danzhou, Hainan, People's Republic of China. www.catas.cn/department/pzs

Keywords: Tropical and subtropical China, collection assessment, preservation, genetic resources utilization, grasses, legumes.

\begin{abstract}
The present status of the collection, preservation and utilization of pasture germplasm in tropical and subtropical zones in China is reviewed. The Tropical Pasture Research Centre (TPRC) of the Chinese Academy of Tropical Agricultural Sciences (CATAS) has been engaged in this research since the 1940s. A low-temperature gene bank, an in-vitro plant library and a nursery station have been established. In total, 5890 indigenous fodder accessions belonging to 478 species, 161 genera and 12 families have been surveyed and collected in South China; 1130 exotic accessions belonging to 87 species and 42 genera of grasses and legumes have been introduced and are preserved. In the seed bank, 3769 accessions from 301 species, 127 genera and 12 families are maintained; in the form of in-vitro culture, 482 accessions belonging to 6 species, 6 genera and 3 families are preserved; and in the plant preservation nursery 388 accessions belonging to 10 species, 8 genera and 3 families. A list of 12 forage legume and 9 grass cultivars released by CATAS during 1991-2011 is presented and suggestions are made for developing and utilizing southern Chinese grassland germplasm resources.
\end{abstract}

\section{Resumen}

Se hace una revisión del estado de la colección, conservación y utilización del germoplasma de forrajes en las zonas tropical y subtropical de China. Desde la década de 1940, el Centro Tropical de Investigaciones en Pastos (TRC, por su sigla en inglés) de la Academia China de Ciencias en Agricultura Tropical (CATAS, por su sigla en inglés) ha estado dedicado a las investigaciones en pastos y forrajes tropicales y subtropicales. Se han establecido un banco de germoplasma para preservación de semillas a baja temperatura, facilidades para la preservación in vitro y facilidades para el mantenimiento de colecciones vivas a nivel de invernadero y campo. En el Sur de China se han hecho exploraciones botánicas y se recolectaron en total 5890 materiales forrajeros nativos pertenecientes a 478 especies, 161 géneros y 12 familias; además, 1130 accesiones exóticas pertenecientes a 87 especies y 42 géneros de gramíneas y leguminosas fueron introducidas y están siendo preservadas. En el banco de semillas se están conservando 3769 accesiones de 301 especies, 127 géneros y 12 familias. La colección conservada en forma de cultivos in vitro comprende 482 accesiones pertenecientes a 6 especies, 6 géneros y 3 familias, y la de plantas vivas mantenidas en invernadero o campo comprende 388 accesiones pertenecientes a 10 especies, 8 géneros y 3 familias. Se presenta una lista con cultivares de 12 leguminosas y 9 gramíneas forrajeras liberadas por CATAS durante 1991-2011 y se hacen algunas recomendaciones para el desarrollo y la utilización de los recursos forrajeros en el Sur de China.

\section{Introduction}

China's tropical and subtropical zones are located between $15^{\circ}$ and $33^{\circ} \mathrm{N}$ and $100^{\circ}$ and $125^{\circ} \mathrm{E}$. The region has $121 \mathrm{M}$ people, $13 \%$ of the total population in China (Liu et al.

Correspondence: Liu Guodao, Tropical Crops Genetic Resources Institute, Chinese Academy of Tropical Agricultural Sciences (CATAS), Danzhou 571737, Hainan, People's Republic of China. Email: $\underline{\text { liuguodao2008@163.com }}$
2008) and covers 260 Mha, including: the entire areas of the Provinces of Guangdong, Hainan, Guangxi, Hunan and Fujian; most parts of Yunnan, Guizhou, Jiangxi, Zhejiang and Sichuan; the southern area of Hubei and Anhui; and small districts of southeast Tibet and southwest Jiangsu Province. The tropical area accounts for 5\% of the South China zone, predominantly in the southern district of Guangdong (Leizhou Peninsula) and all of Hainan Province. Arable land occupies 28 Mha (10.7\% of the region), forests 90 Mha (34.6\%) and grasslands 79 Mha (30.4\%). 
Tropical China is a warm climate area with plentiful rainfall without an obvious winter and separate wet (generally May-October) and dry seasons. The range of average annual rainfall in the region is $1200-2500 \mathrm{~mm}$, the average annual temperature $20-26{ }^{\circ} \mathrm{C}$ and the accumulated temperature above $10{ }^{\circ} \mathrm{C}$ is 7900 degree days. It is more mountainous in the northern and western areas, with upland and river plain topographies in the coastal areas of the southeast. The mountainous and upland area covers more than $30 \%$ of the region and is unsuitable for cash crops except forage production. Forage plant resources are abundant in cleared areas. The current status of vegetation is secondary forest (coniferous, broad-leaf, shrubland and coppiced forests), grassland and agricultural land. The grasslands include savanna, shrubland, coppiced forest and arable land sown with exotic legumes and grasses. Most of the grasslands are distributed in small areas belonging to smallholder farmers, with a potential for forage intercropping with cash crops, rubber and fruit tree plantations. Most of the tropical and subtropical regions of South China experience good climatic conditions with enough heat and water to support good growth of forage plants. Despite the degradation resulting from fire, overgrazing and cutting of vegetation for fuel and organic matter input for cropland, native plants with forage potential remain a valuable resource.

This paper reviews the scale of forage plant resources in southern China and the programs to identify, evaluate and utilize these forages, and concludes with a discussion of current issues and possible solutions.

\section{Surveys of tropical and subtropical forage genetic re- sources}

In the past 50 years, 6707 forage and feed plant species belonging to 1545 genera in 246 families were surveyed. During 1978-1990, the Chinese Academy of Agricultural Science (CAAS) collected: 4125 species of natural forages for possible cultivation and breeding, belonging to 879 genera within 127 families; 972 species from 173 grass genera; and 646 species from 81 legume genera. The species came from Hainan (1067), Guangdong (482), Yunnan (698), Guizhou (1400), Sichuan (232), Jiangxi (733), Anhui (255) and Hubei (931). In 1980, the National Grassland Survey identified more than 1000 species belonging to 190 grass genera, and 791 species belonging to 120 legume genera on natural grassland areas of the 14 southern provinces (Flora of Hainan 1979; Flora of Fujian 1995; Flora of Yunnan 2003; Flora of Guangdong 2007).

In South China, there are 4680 known species with forage potential (Table 1), mostly dicotyledons. The most highly regarded potential forage plant resources in South China include 687 species ("productive species" in Table 2), among them 364 grass species and 87 legume species. Among these indigenous species, 354 species are endemic, including 67 grass and 45 legume species; some are already used for livestock production (Wu 1961; Liu 2000). The variable topography and climate in Hainan Island have produced a very large number of tropical species within the rich Chinese flora, composed of 25000 species of higher plants. CAAS first surveyed the indigenous forage plant resources in 1983, and recorded 119 species (Li 2000; Shi et al. 2008). Hainan provincial research units then surveyed forage resources in 1986 and recorded 567 species. Subsequently CATAS in Hainan recorded 1048 forage plant species in 1993. During 2004-2009, a total of 242 species of grasses were investigated and details recorded, including morphological characteristics, habitat and ecogeographic distribution. Some of these forage germplasm resources are species introduced from outside Hainan $(\mathrm{Wu}$ 1961; Flora of Fujian 1995; Liu 2000; Flora of Yunnan 2003; Flora of Guangdong 2007; Yin et al. 2008).

Forage germplasm resources exploitation is based on collection and effective preservation as part of a longterm strategy to identify, evaluate and utilize forages. So far about 6000 forage germplasm samples have been

Table 1. Composition of indigenous plants with forage and feeding potential in South China.

\begin{tabular}{|c|c|c|c|c|c|c|}
\hline Category & $\begin{array}{l}\text { Families } \\
\text { (No.) }\end{array}$ & $\begin{array}{l}\text { Proportion of total } \\
\text { families }(\%)\end{array}$ & $\begin{array}{c}\text { Genera } \\
\text { (No.) }\end{array}$ & $\begin{array}{l}\text { Proportion of total } \\
\text { genera }(\%)\end{array}$ & $\begin{array}{l}\text { Species } \\
\text { (No.) }\end{array}$ & $\begin{array}{c}\text { Proportion of } \\
\text { total species } \\
(\%)\end{array}$ \\
\hline Ferns & 14 & 5.3 & 31 & 2.3 & 46 & 1.0 \\
\hline Gymnosperms & 8 & 3.1 & 16 & 1.2 & 63 & 1.4 \\
\hline Angiosperms & 240 & 91.6 & 1303 & 96.2 & 4571 & 97.7 \\
\hline Dicotyledons & 218 & 83.2 & 1068 & 79.1 & 3704 & 79.2 \\
\hline Monocotyledons & 22 & 8.4 & 235 & 47.4 & 567 & 18.5 \\
\hline Total & 262 & 100.0 & 1350 & 100.0 & 4680 & 100.0 \\
\hline
\end{tabular}


collected; most are preserved and only a limited number have been evaluated for their forage potential. There are still many other plant materials to be preserved and evaluated. For example, it is reported that the indigenous forage and feed plant resources in South China comprise 123 families (Table 2), but only 12 families have been collected. According to the Floras of Hainan, Guangdong, Guangxi and Fujian, there are 364 grass species in 92 genera, but only 38 species have been collected and preserved. Future work in South China will place more emphasis on collecting rare and endangered populations with forage potential, including those with pest and disease resistance.

Table 2. Categories of potential forage and feeding resources in South China.

\begin{tabular}{lccc}
\hline Category of forage resource & $\begin{array}{c}\text { Families } \\
(\text { No. })\end{array}$ & $\begin{array}{c}\text { Genera } \\
\text { (No.) }\end{array}$ & $\begin{array}{c}\text { Species } \\
(\text { No. })\end{array}$ \\
\hline Indigenous species & 123 & 587 & 1432 \\
Endemic species & 85 & 128 & 354 \\
Rare and endangered species & 53 & 120 & 152 \\
Productive species & 25 & 243 & 687 \\
\hline
\end{tabular}

\section{Methodological aspects of collection, reproduction and preservation}

\section{Collection and investigation}

The collection of indigenous forage germplasm resources includes 3 stages: finding and identifying forage genera and species; recording ecological descriptors (local vegetation type, soils, topographical features and climatic data); and passport data on location (latitude, longitude, elevation and map reference), registration numbers, collector names etc. The investigation of indigenous forage germplasm uses 4 stages: field investigation, including visiting local farmers; data descriptors of forages; planting in greenhouse, reproduction, vegetative multiplication and preliminary evaluation; and field investigations. The collection and investigation processes overlap. Identification of sites for collection will sometimes be based on experience or every $30-50 \mathrm{~km}$ along accessible roads or tracks. Collectors aim to obtain mature seeds where possible, or else tillers, stems, seedlings, tubers or other propagule material. When exotic forage genetic resources are introduced, the aims are to obtain similar levels of background information and to maintain bio-security.

\section{Reproduction}

The number of seeds collected in the field is usually limited, so there is need to produce enough seeds for preser- vation and further evaluation. Reproduction is done in the greenhouse, shadehouse or in the field. Seeds are treated to enhance germination, e.g. breaking hardseededness in some groups. Some legumes and grasses are propagated vegetatively.

\section{Preservation}

The storage of seeds is the most efficient way to preserve tropical and subtropical forage germplasm resources. Seeds are stored at low temperature, humidity and oxygen to increase their longevity. Both long-term and short-term storage are used at TPRC, CATAS. Long-term storage uses -20 to $-15{ }^{\circ} \mathrm{C}$ and relative humidity (RH) of $12-15 \%$, which should maintain seed viability for $>25$ years; shortterm storage uses $0-5{ }^{\circ} \mathrm{C}$ and RH $12-15 \%$ to keep seeds for up to 5 years. Seeds are sealed in aluminium foil bags containing 15 000 seeds. Germination and moisture content of seeds are tested before storage and again every 3-5 years.

\section{Current status of forage genetic resources evaluation and preservation in South China}

By 2006, the National Animal Husbandry and Veterinary Service, Ministry of Agriculture, had evaluated national forage germplasm resources preservation for more than 10 years. The national forage germplasm resources preservation system that was established includes a central gene bank, 2 duplicate gene banks, 15 nurseries and 10 collaboration teams from different ecosystem-regions in China. The central seed bank of the state forage germplasm resources center has collected, from 1998 to 2006, 9500 samples of forage germplasm resources from 1000 species, 411 genera and 67 families from all over the country. To date, more than 18000 accessions have been collected and are preserved in the central gene bank, and the agronomic characteristics of more than 12000 accessions have been described. The productivity of more than 1500 accessions was evaluated. A total of 45 grasses and 28 legumes were identified with good forage potential; 96 plant lines became the basis for recent forage breeding.

Forage genetic resources have been under severe threats resulting from: (1) natural factors, including environmental and climate change, greenhouse effect, ozone increase, fire, soil degradation and serious pollution; (2) infrastructure development, land management and land use changes, such as building of roads and railways, mining, new industrial developments, urbanization, transformation of forests or grasslands into cropland, cutting of vegetation for fuel, overgrazing and other activities that destroy farmland; (3) scientific and technological innovation, including the planting of new varieties, application of fertilizer and 
mechanization of agriculture; and (4) the replacement of old locally evolved varieties by introduced species, cultivars and agronomic practices (Jiang 1996; Li 2000; Zhang et al. 2003; Wang et al. 2007; Zhao 2009). The TPRC at CATAS assumed responsibility for the collection and preservation of tropical and subtropical forage resources in 1940; 5890 indigenous accessions, belonging to 478 species, 161 genera and 12 families, have been surveyed and collected in Hainan, Guangdong, Guanxi, Fujian and South Yunnan provinces.

Tropical areas account for only 5\% of South China; here, tropical indigenous plant resources are very limited. To date cultivated forage varieties have come mostly from 4 centers of origin in the world ( $\mathrm{He} 1986)$ : The tropical African savannas are the source of many cultivated grasses, such as bluestem (Andropogon spp.), panic and guinea grasses (Panicum spp.), pennisetum grass (Pennisetum spp.), bristlegrass (Setaria spp.) and brachiaria grasses (Brachiaria spp.). Tropical America is the source of a number of cultivated tropical grasses, such as carpet grass (Axonopus spp.), paspalum (Paspalum spp.) and gama grass (Tripsacum spp.), but is mainly the source of many tropical cultivated forage legumes, such as stylo (Stylosanthes spp.), centro (Centrosema spp.), large-wing bean (Macroptilium spp.), leucaena (Leucaena spp.) and calopo (Calopogonium spp.). Tropical Africa is the source of other cultivated legume varieties such as cowpea (Vigna spp.), indigo (Indigofera spp.) and alysicarpus (Alysicarpus spp.) (Liu 2000; Yu et al. 2006).

The introduction of tropical forages into China started as early as the 1940s, when elephant grass (Pennisetum purpureum) was first introduced from Southeast Asian countries. In 1982 the NSW Department of Primary Industries, Australia introduced and tested a wide range of tropical and subtropical grasses and legumes in Hainan (Michalk et al. 1993a; 1993b) and Guangdong (Michalk and Huang 1994a; 1994b). After that TPRC began to gradually introduce forage genetic resources from the International Center for Tropical Agriculture (CIAT), the Australian Centre for International Agricultural Research (ACIAR), the Brazilian Agricultural Research Corporation (EMBRAPA) and others. Now, a total of 1130 exotic accessions from 87 species and 42 genera, of which 12 genera are exotic, have been introduced and preserved (Table 3).

In 2009, TPRC launched a project for the preservation of tropical and subtropical forage germplasm resources. As the leading unit in South China, it established a seed gene library using low temperature preservation, an in-vitro preservation library and a nursery station for plant propagation. The seed copy bank of tropical and subtropical forage germplasm resources has collected and is preserving 3769 accessions, the conservation library has 482 accessions and the nursery station has 388 accessions (Table 4).

Table 3. Tropical and subtropical regional forage genetic resources in South China.

\begin{tabular}{|c|c|c|c|c|c|c|c|}
\hline Family & $\begin{array}{c}\text { Genera } \\
\text { (No.) }\end{array}$ & $\begin{array}{c}\text { Species } \\
\text { (No.) }\end{array}$ & $\begin{array}{c}\text { Accessions } \\
\text { (No.) }\end{array}$ & $\begin{array}{c}\text { Indigenous } \\
\text { species } \\
\text { (No.) }\end{array}$ & $\begin{array}{c}\text { Indigenous } \\
\text { accessions } \\
\text { (No.) }\end{array}$ & $\begin{array}{l}\text { Exotic } \\
\text { species } \\
\text { (No.) }\end{array}$ & $\begin{array}{c}\text { Exotic } \\
\text { accessions } \\
\text { (No.) }\end{array}$ \\
\hline Fabaceae & 72 & 246 & 3390 & 210 & 2852 & 36 & 538 \\
\hline Poaceae & 89 & 252 & 3078 & 224 & 2840 & 28 & 238 \\
\hline Compositae & 3 & 3 & 7 & 3 & 7 & & \\
\hline Amaranthaceae & 2 & 6 & 87 & 6 & 87 & & \\
\hline Euphorbiaceae & 2 & 2 & 385 & 2 & 31 & 1 & 354 \\
\hline Malvaceae & 1 & 1 & 2 & 1 & 2 & & \\
\hline Sapindaceae & 1 & 1 & 9 & 1 & 9 & & \\
\hline Urticaceae & 1 & 1 & 1 & 1 & 1 & & \\
\hline Cyperaceae & 13 & 21 & 47 & 21 & 47 & & \\
\hline Convolvulaceae & 1 & 1 & 1 & 1 & 1 & & \\
\hline Labiatae & 1 & 1 & 1 & 1 & 1 & & \\
\hline Acanthaceae & 1 & 1 & 1 & 1 & 1 & & \\
\hline Cruciferae & 2 & 3 & 5 & 3 & 5 & & \\
\hline Polygonaceae & 1 & 3 & 6 & 3 & 6 & & \\
\hline Total & 190 & 542 & 7020 & 478 & 5890 & $65^{1}$ & 1130 \\
\hline
\end{tabular}

${ }^{1}$ A total of 87 species have been introduced and are preserved, of which 65 species are exotic and 23 species are both indigenous and exotic, such as cassava (Manihot esculenta). 
Table 4. Composition of tropical and subtropical forage genetic resources in different types of preservation at TPRC, CATAS.

\begin{tabular}{|c|c|c|c|c|}
\hline Type of preservation & Family & $\begin{array}{c}\text { Genera } \\
\text { (No.) }\end{array}$ & $\begin{array}{c}\text { Species } \\
\text { (No.) }\end{array}$ & $\begin{array}{c}\text { Accessions } \\
\text { (No.) }\end{array}$ \\
\hline \multirow{13}{*}{ Low temperature preservation in genebank } & Fabaceae & 67 & 204 & 3161 \\
\hline & Poaceae & 35 & 56 & 443 \\
\hline & Compositae & 2 & 3 & 7 \\
\hline & Amaranthaceae & 2 & 6 & 87 \\
\hline & Sapindaceae & 1 & 1 & 9 \\
\hline & Convolvulaceae & 1 & 1 & 1 \\
\hline & Cruciferae & 2 & 3 & 5 \\
\hline & Polygonaceae & 1 & 3 & 6 \\
\hline & Cyperaceae & 13 & 21 & 47 \\
\hline & Labiatae & 1 & 1 & 1 \\
\hline & Acanthaceae & 1 & 1 & 1 \\
\hline & Malvaceae & 1 & 1 & 1 \\
\hline & Total & 127 & 301 & 3769 \\
\hline \multirow[t]{4}{*}{ Preservation in vitro } & Fabaceae & 4 & 4 & 21 \\
\hline & Poaceae & 1 & 1 & 61 \\
\hline & Euphorbiaceae & 1 & 1 & 400 \\
\hline & Total & 6 & 6 & 482 \\
\hline \multirow[t]{4}{*}{ Preservation in nursery } & Fabaceae & 1 & 1 & 6 \\
\hline & Poaceae & 6 & 8 & 58 \\
\hline & Euphorbiaceae & 1 & 1 & 324 \\
\hline & Total & 8 & 10 & 388 \\
\hline
\end{tabular}

\section{State of forage germplasm resources}

The grass industry in South China has achieved productive results in the cultivation and breeding of forage species from introduced and native germplasm for grassland improvement, resistance to diseases and insect pests, intercropping between fruit or forest trees, coastal dune stabilization and utilization as livestock feed. In 1986, the National Approval Committee for Pasturage Species held its first meeting to approve forage species and by 2012, 453 cultivars had been registered, of which 120 cultivars (50 legumes and 70 grasses) are suitable for southern China (Liu et al. 2008). The TPRC at CATAS has successively selected, bred and released 19 cultivars (Table 5). These varieties have been used across the southern and southwest provinces in China. They are used not only for grazing and producing high-quality hay and forage meal, but also widely for green manure, young rubber tree gardens, soil cover in orchards, conservation of soil and water, fixing of coastal sand into soil, as well as environmental greening and beautification, expanding the function and role of tropical pasturage and bringing new concepts to the development of the grass industry in South China.

Stylosanthes guianensis Reyan No. 2 has been planted on over 2 Mha in Hainan, Guangdong, Guangxi, Hunan, Jiangxi, Jiangsu, Yunnan, Guizhou, Sichuan, Fujian and other regions. Pennisetum americanum (Wang grass Reyan
No. 4) has been planted over 10 Mha in Xinjiang, Beijing, Hubei, southern China and the southwest, and is used as a solution to the problem of shortage of winter feed in parts of the northern region. The Fujian Agricultural and Scientific Institution has bred and released productive cultivars of Chamaecrista (syn. Cassia) rotundifolia and Brachiaria hybrid No. 1. Due to their advantages, such as fast growth, good soil cover, strong ability to fix nitrogen (in the case of legumes), good pest and disease resistance and increased nutritive value, they have obvious superiority in the conservation of water and soil, and ecological and soil fertility restoration. The Yunnan Research Centre for Beef Cattle and Pasturage has released 7 cultivars (among them Weichite Eastern Pennisetum, Haifa white clover, white clover and Shafulei Kenya clover), which are planted over 8 Mha in Yunnan, Guizhou and neighboring areas.

\section{The problems}

\section{The danger of losing tropical forage resources}

The acknowledged degradation problems in Chinese grassland ecology are a major threat to the preservation of indigenous forage species. With the rapid development of the economy in South China, grassland, forest and rangeland areas have been considerably reduced in area and what remains is under increased pressure to feed the large 
Table 5. Tropical forage varieties released by CATAS.

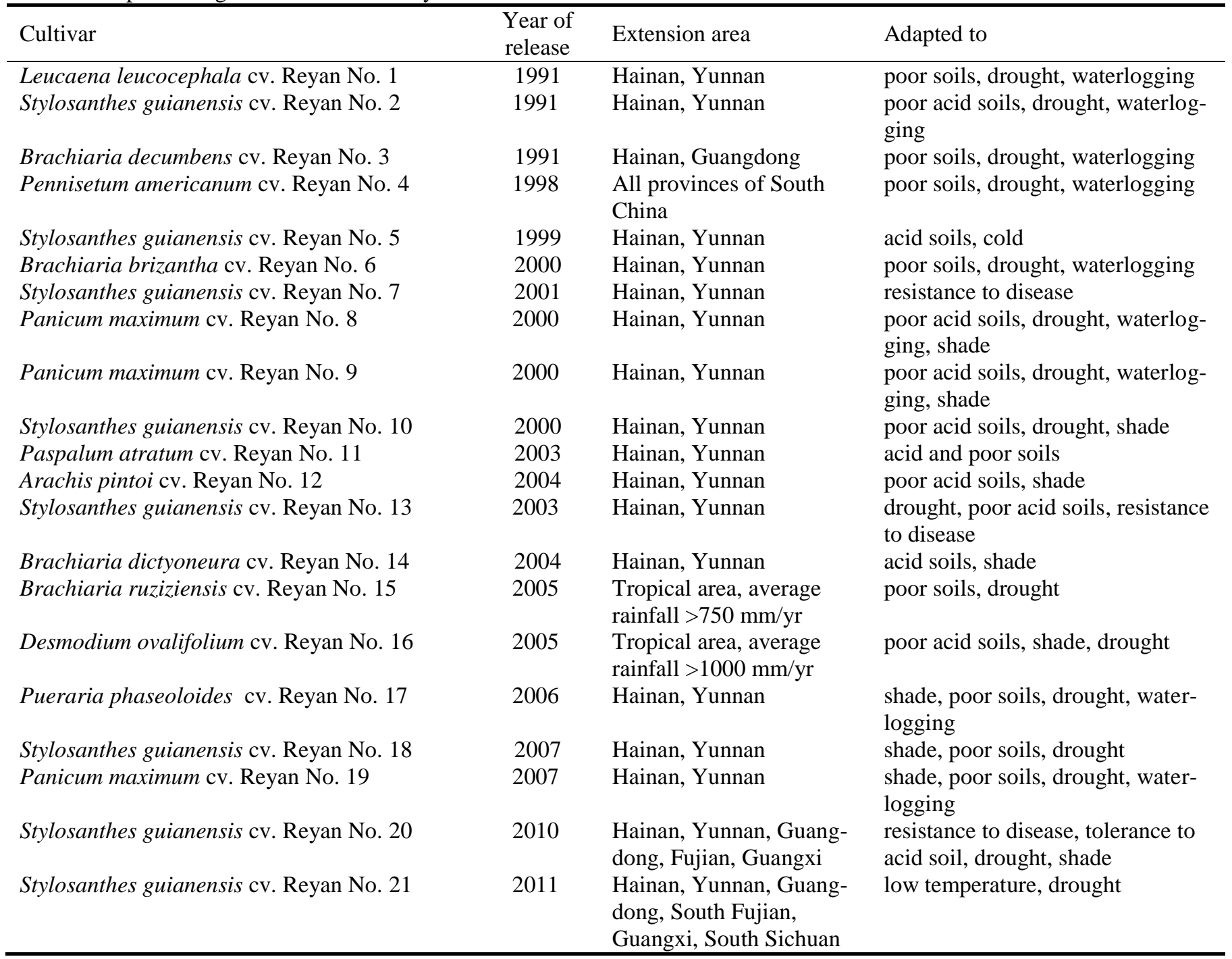

population. Some varieties and genotypes of productive forage species are disappearing as a result of these pressures, threatening genetic diversity. Preservation practices are by necessity a compromise, which means that only some genotypes will be preserved. Field evaluation of genotypes lags considerably behind the acquisition of material, such that valuable genotypes may not be tested or could be lost in storage. Genetic drift/loss is a real risk with cross-pollinated species (Yan et al. 2008). A consequence of these factors is that forage species do need to be maintained in the wild and collections renewed at intervals.

\section{The limited use of collections}

The work on the identification and utilization of tropical pasture germplasm has not been sufficient to thoroughly appraise this resource and to maximize gains. There is still only a general understanding of what ecotypes are in the collections and a poorer understanding of any special traits that may be there. Breeding work has been limited. The cultivars released, while being an improvement on existing material, are based only on limited selection, though it is considered that the total resource is a rich one.

\section{Limitations in preservation and preservation technology}

The strategy adopted to collect and preserve material is relatively standard and designed to handle larger amounts of material with some efficiency. It has not been possible to develop and use more innovative preservation techniques, especially for those species that may have unusual reproductive strategies. It is anticipated that techniques such as asexual reproduction, tissue culture, cloning and pollen storage, as well as advanced techniques for storing 
DNA etc., will need to be developed and used to maintain the collections and their genetic diversity (Yan et al. 2008). These techniques would aim to speed up the identification and utilization of improved material.

\section{Barriers to the availability and usage of germplasm}

Germplasm is a common good and arguably should belong freely to the community, although opinions vary around the world. Any benefits from exploiting these resources should be available to the community - be it at the country, provincial or local level. Intellectual property rights is, in many places, an issue that is still to be resolved. By retaining the rights of forage resources in public hands, there is more chance for the wider community to benefit.

\section{Suggestions}

Strategies to survey, collect and introduce forage resources

Any selection and breeding program needs to have significant genetic diversity to maximize the chance of producing good cultivars. Programs need to expand to include more exotic material as well as local collections of the same species.

\section{Improvement in modification of genetic material}

Research needs to identify those traits that significantly enhance the quantity and quality of forage produced. A range of techniques, including genetic engineering, then need to be used to produce germplasm for testing and eventual release.

\section{Strengthen use of new cultivars with independent intellec- tual property rights}

There are few tropical forage cultivars with independent intellectual property rights. This needs to be encouraged to stimulate cultivar development.

\section{Promote sharing of resources}

Scientific progress depends upon the sharing of information. Greater sharing of genetic material and collabo-ration in breeding programs to generate more productive forage cultivars would enhance the development of forage resources in southern China. Appropriate protocols for sharing material need to be developed.

\section{References}

Flora of Fujian. 1995. Science and Technology Commission of Fujian Province. Fujian Science and Technology Press, Fuzhou, PR China.

Flora of Guangdong. 2007. South China Botanical Garden, Chinese Academy of Sciences. Guangdong Science and Technology Press, Guangzhou, PR China.

Flora of Hainan. 1979. South China Institute of Botany, Chinese Academy of Sciences. Science Press, Beijing, PR China.

Flora of Yunnan. 2003. Kunming Institute of Botany, Chinese Academy of Sciences. Science Press, Beijing, PR China.

He CZ. 1986. An introduction of technology on forage germplasm resource research. Grassland and Turf 4:50-53.

Jiang YQ. 1996. The achievements and prospects of research on forage germplasm resources in China. Journal of Northeast Normal University 13:93-96.

Li XF. 2000. A thought of forage germplasm resource preservation and utilization. Grassland of China 5(2):74-75.

Liu GD. 2000 Flora of Hainan tropical forage. Chinese Agriculture Press, Beijing, PR China.

Liu GD; Michalk DL; Bai CJ; Yu DG; Chen ZQ. 2008. Grassland development in tropical and subtropical southern China. The Rangeland Journal 30:255-270.

Michalk DL; Fu NP; Zhu CM. 1993a. Improvement of dry tropical rangelands in Hainan Island, China: 1. Evaluation of pasture legumes. Journal of Range Management 46: 331-339.

Michalk DL; Fu NP; Zhu CM. 1993b. Improvement of dry tropical rangelands in Hainan Island, China: 2. Evaluation of pasture grasses. Journal of Range Management 46:339-345

Michalk DL; Huang ZK. 1994a. Grassland improvement in subtropical Guangdong Province, China: 1. Evaluation of pasture legumes. Tropical Grasslands 28:129-138.

Michalk DL; Huang ZK. 1994b. Grassland improvement in subtropical Guangdong Province, China: 2. Evaluation of pasture grasses. Tropical Grasslands 28:139-145.

Shi WG; Li ZY; Wang YQ. 2008. Documentation concordance and share of forage germplasm resources. Journal of Plant Genetic Resources 9:561-565.

Wang TM; Zhang JN; Lu XS. 2007. Development strategies of forage germplasm resources in China. Chinese Journal of Grassland 129(13):104-108.

Wu ZY. 1961. Flora of China. Editorial Committee of the Chinese Academy of Sciences, Beijing, PR China.

Yan XB; Wang CZ; Guo YX. 2008. Storage, utilization and conservation of forage germplasm in China. Pratacultural Science 25(12):85-91.

Yin J; Sun Z; Wei Q. 2008. Current status and prospect of forage germplasm resources in Yunnan province. Pratacultural Science 25(10):88-94.

Yu DG; Liu GD; Bai CJ. 2006. A survey on indigenous fodder germplasm and study on indigenous fodder development and utilization. Chinese Agricultural Science Bulletin 122: 416-420. 
Zhang JY; Yuan QH; Zhang WS. 2003. The advances in study on forage germplasm resources and its genetic diversity in China. Grassland of China 8(2):59-65.
Zhao LX. 2009. The potentiality and countermeasures of collection, valuation and utilization of excellent forage germplasm resources in China. Acta Agrestia Sinica 1:413-419.

(C) 2013

\section{(c) $(1)(2)$}

Tropical Grasslands-Forrajes Tropicales is an open-access journal published by Centro Internacional de Agricultura Tropical (CIAT). This work is licensed under a Creative Commons Attribution-NonCommercial-ShareAlike 3.0 Unported License. To view a copy of this license, visit http://creativecommons.org/licenses/by-nc-sa/3.0/ 
Bai Changjun; Liu Guodao; Zhang Yu; Yu Daogeng; Yan Linling. 2013. Technical challenges in evaluating southern China's forage germplasm resources. Tropical Grasslands - Forrajes Tropicales 1:184-191.

DOI: $\underline{\text { 10.17138/TGFT(1)184-191 }}$

This paper was presented at the $22^{\text {nd }}$ International Grassland Congress, Sydney, Australia, 15-19 September 2013. Its publication in Tropical Grasslands - Forrajes Tropicales is the result of a co-publication agreement with the IGC Continuing Committee. Except for adjustments to the journal's style and format, the text is essentially the same as that published in: Michalk LD; Millar GD; Badgery WB; Broadfoot KM, eds. 2013. Revitalising Grasslands to Sustain our Communities. Proceedings of the $22^{\text {nd }}$ International Grassland Congress, Sydney, Australia, 2013. New South Wales Department of Primary Industries, Orange, NSW, Australia. p. 359-364. 